\title{
Data report: Pleistocene radiolarian biostratigraphy, IODP Expedition 346 Site U1427'
}

\author{
Takuya Itaki, ${ }^{2}$ Takuya Sagawa, ${ }^{2}$ and Yoshimi Kubota ${ }^{3}$
}

\section{Chapter contents}

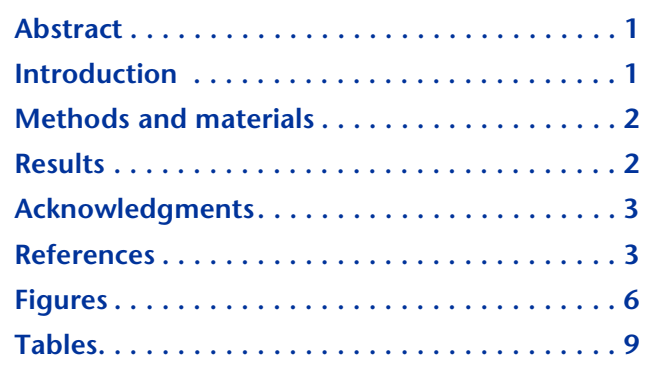

${ }^{1}$ Itaki, T., Sagawa, T., and Kubota, Y., 2018. Data report: Pleistocene radiolarian biostratigraphy, IODP Expedition 346 Site U1427. In Tada, R., Murray, R.W., Alvarez Zarikian, C.A., and the Expedition 346 Scientists, Proceedings of the Integrated Ocean Drilling Program, 346: College Station, TX (Integrated Ocean Drilling Program). doi:10.2204/iodp.proc.346.202.2018

${ }^{2}$ AIST, Geological Survey of Japan, Higashi 1-1-1, Tsukuba Central 7, Ibaraki 305-8567, Japan. Correspondence author: t-itaki@aist.go.jp ${ }^{3}$ Department of Geology and Paleontology, National Museum of Nature and Science, Amakubo 4-1-1, Tsukuba, Ibaraki 305-0005, Japan.

\section{Abstract}

Quantitative analysis of radiolarian assemblages was conducted on sediment cores collected from the seafloor during Integrated Ocean Drilling Program Expedition 346. During Expedition 346, Site U1427 was cored in the shelf region of the Yamato Basin, southern Japan Sea, to $570 \mathrm{~m}$ core composite depth below seafloor (CCSF-A) in Hole U1427A. Radiolarian biostratigraphy conducted for this site identified four datum levels: last occurrence (LO) of Lychnocanomma sakaii (0.054 Ma), LO of Amphimelissa setosa (0.085 Ma), LO of Schizodiscus japonicus (0.29 Ma), and first occurrence (FO) of Amphimelissa setosa ( 1.48 Ma). In addition, the abundance maxima of subtropical water species, which indicate migration of the Tsushima Warm Current from the East China Sea associated with eustatic sea level rise during interglacial periods, are most likely correlated with the marine isotope stages during the past $1.5 \mathrm{My}$.

\section{Introduction}

Integrated Ocean Drilling Program (IODP) Expedition 346 was conducted on the shelf region of the Yamato Basin off the San'in District of southwest Japan (Fig. F1). At Site U1427 (water depth = $330 \mathrm{~m}$ ), a hole was cored to $570 \mathrm{~m}$ core composite depth below seafloor (CCSF-A) (see the "Expedition 346 summary" chapter [Tada et al., 2015a]). At this site, both calcareous and siliceous microfossils are well preserved in all cores, and a high sedimentation rate (264-630 m/My) over the past 1.4 My was estimated based on biostratigraphy and magnetostratigraphy (see "Biostratigraphy" and "Stratigraphic correlation and sedimentation rates" in the "Site U1427" chapter [Tada et al., 2015b]). Therefore, this drill site was expected to be suitable for paleoceanographic study with high-resolution analysis.

In this report, we provide an updated data set of the available radiolarian datum levels and the abundance of subtropical water species based on 455 samples from Site U1427. Because subtropical radiolarians are closely related to the inflow of the Tsushima Warm Current (TWC) from the East China Sea via the Tsushima Strait (sill depth $=130 \mathrm{~m}$ ), their abundance can be correlated with marine isotope stages (MIS). In addition, a portion of the initial shipboard results of the planktonic foraminiferal biostratigraphy (Tada et al., 2015a) has been reinterpreted herein to improve the 
detailed age model, especially for the lower part of the sequence.

\section{Methods and materials}

This study is based on 455 samples that were collected at almost uniform intervals within Holes U1427A, U1427B, and U1427C. Sample preparation for light microscopy observation was conducted as follows:

1. Freeze-dried sediment samples were weighed and treated with $10 \% \mathrm{H}_{2} \mathrm{O}_{2}$ and $10 \% \mathrm{HCl}$ solution to remove organic matter and calcium carbonate, respectively.

2. The samples were then wet sieved and rinsed using a $45 \mu \mathrm{m}$ mesh sieve, after which two types of slides were made of the residue for two purposes: quantify abundance (Q-slide) and faunal analysis (F-slide).

3. To prepare Q-slides, residue was transferred to a $200 \mathrm{~mL}$ beaker containing $100 \mathrm{~mL}$ of water. The solution was then mixed well, after which a 0.5 $\mathrm{mL}$ sample was taken from the suspension using a micropipette and dropped onto a glass slide. The sample was then dried and mounted with Norland optical adhesive and covered with a 22 $\mathrm{mm} \times 18 \mathrm{~mm}$ cover glass.

4. F-slides were made from the remaining residue in the beaker. Because our samples had large lithogenic grain content, opal particles were extracted from the residue using the elutriation method (Itaki, 2006). The extracted particles were mounted with Norland optical adhesive and covered with $22 \mathrm{~mm} \times 36 \mathrm{~mm}$ cover glasses. The adhesive was solidified by placing the slide under UV light for 15 min.

5. Slides were partially examined at $50 \times$ to $400 \times$ for stratigraphic markers and other common taxa under a Zeiss Axio imager microscope.

The total number of radiolarians in $1 \mathrm{~g}$ of dry sediment was estimated using the following equation:

Total radiolarian content (individuals $/ \mathrm{g}$ ) $=$ total number of individuals on Q-slide $x$ 200/sample weight (g).

Relative abundance (percent of total assemblage) of subtropical species was estimated by counting and identifying more than 200 individuals on the F-slide; however, when radiolarian individuals were scarce, as many as could be identified were counted. The ab- solute abundance of subtropical species (individuals/ g) was converted using the following equation:

Subtropical species (individuals $/ \mathrm{g}$ ) $=$ total radiolarians (number of individuals $/ \mathrm{g}$ ) $\times$ subtropical species (\%)/100.

Although very few counts often cause inaccurate relative percent data, the absolute abundance (individuals/g) estimated from the few counts shows low values regardless of count numbers. Therefore, the absolute abundance is used for illustrating abundance changes of subtropical species in this report (Table T1).

For key species used as biostratigraphic datums, their occurrence or absence was checked over the entire slide (Table T1). Taxonomic framework was adapted from Itaki et al. (2007) and Matsuzaki et al. (2014).

This report follows the Geological Time Scale 2012 (GTS 2012) of Gradstein et al. (2012).

\section{Results \\ Datum levels}

Four datum levels of radiolarian marker species were recognized at Site U1427 (Table T2). The last occurrences (LOs) of Lychnocanomma sakaii (Morley and Nigrini) and Amphimelissa setosa (Cleve) are well known biohorizons in the subarctic Pacific Ocean and its marginal seas (e.g., Kruglikova, 1976; Matul et al., 2002; Okazaki et al., 2005; Tanaka and Takahashi, 2005; Itaki et al., 2009), and their ages have been estimated in the Japan Sea as 0.054 and 0.085 Ma, respectively (Itaki et al., 2007), according to an age model based on oxygen isotope stratigraphy and widespread tephra layers (Kido et al., 2007).

The LO of Schizodiscus japonicus Matsuzaki et al. (2014) is the same as the reported LO of Spongodiscus sp. in the North Pacific Ocean (Ling 1975; Sakai, 1980), the Bering Sea (Ling, 1973; Ikenoue et al., 2016), and the Sea of Okhotsk (Matul et al., 2002). In the Sea of Okhotsk, this datum has been found in MIS 9 (0.29 Ma) (Matul et al., 2002) or MIS 8.5 (0.27 Ma) (Matul et al., 2009).

The first occurrence (FO) of Amphimelissa setosa was recorded at $544 \mathrm{~m}$ CCSF-A at Site U1427. Using an astronomically tuned age model, the first common occurrence (FCO) of this species at IODP Site U1341 in the Bering Sea was dated at $\sim 1$ Ma (Ikenoue et al., 2016). Most recently, Matsuzaki and Suzuki (2018) 
report that the FO of this species occurred at $1.48 \mathrm{Ma}$ in the Gulf of Alaska, the eastern subarctic Pacific.

\section{Subtropical water species}

The Tsushima Warm Current (TWC) flows into the Japan Sea through the Tsushima Strait (sill depth = $130 \mathrm{~m}$ ) from the East China Sea, which is the only source of oceanic water in this sea. It is known that inflow of the TWC was strongly restricted during middle to late Pleistocene glacial periods due to a eustatic fall in sea level causing the closure of the Tsushima Strait (e.g., Oba et al., 1991; Kido et al., 2007). The radiolarian taxon Tetrapyle octacantha group, which is a subtropical species restricted to the TWC in this region, was common during interglacial periods but rare during glacial periods over the past 0.64 My (Itaki et al., 2007; Itaki, 2007), suggesting that occurrences of such subtropical species can be related to the sea level fluctuations and TWC flow into the southern Japan Sea.

Figure F2 illustrates the stratigraphic changes in the abundance of subtropical radiolarians together with the depths of biostratigraphic datum levels. Subtropical radiolarians include Tetrapyle octacantha group, Dictyocoryne spp., Didymocyrtis tetrathalamus, Euchitonia spp., and Spongaster tetras, all of which are common in the Kuroshio Current area through the tropical-subtropical Pacific (e.g., Lombari and Boden, 1985) and the East China Sea (Chang et al., 2003). In the Japan Sea, their distributions show a close relation to the TWC (Motoyama et al., 2016).

Total abundance of subtropical radiolarians shows cyclic fluctuation ranging between 0 and 600 individuals/g through the succession, and their abundance maxima are most likely correlated to the interglacial periods during the early Pleistocene to Holocene (Fig. F2). Although correlations of abundance peaks to MIS 1, 5, 7, and 9 are consistent with interpolation among biostratigraphic horizons such as the LO of L. sakaii, A. setosa, and S. japonicus for the upper part of the cored record (Fig. F2), the more numerous peaks below $290 \mathrm{~m}$ CCSF-A are sometimes difficult to assign correctly due to few available tie points in the age model. To determine if this correlation could be improved, we reviewed the onboard results of the planktonic foraminiferal biostratigraphy, especially the coiling ratio of Neogloboquadrina pachyderma and the \#2 Globorotalia inflata bed, which are well-known biostratigraphic markers in the Japan Sea (e.g., Maiya et al., 1976).

In Figure F3, biohorizons of the $N$. pachyderma coiling ratio and the position of the top \#2 G. inflata bed at Site U1427 are correlated with Ocean Drilling Program (ODP) Leg 128 Site 798 in the southern Japan
Sea (Kheradyar, 1992) and Core V20-199 in the northwestern Pacific Ocean (Maiya et al., 1976).

Maiya et al. (1976) describes three datums based on the $N$. pachyderma coiling ratio as the younger peak (Datum A), older peak (Datum B), and significant drop of the ratio (Datum C) and estimates their ages in Core V20-119 based on interpolation between paleomagnetic datums. According to the most updated GTS 2012, the ages of Datums A, B, and C of the $N$. pachyderma coiling ratio in Core V20-119/Site 798 could be dated to $1.12-1.13 \mathrm{Ma}, 1.21-1.23 \mathrm{Ma}$, and 1.26-1.29 Ma, respectively, based on interpolation between the base of Chron C1r.1n (1.072 Ma) and the top of Chron C2n (1.778 Ma). Similarly, top \#2 G. inflata bed could be placed at $1.30 \mathrm{Ma}$ at Site 798. Kitamura and Kimoto (2004) note that the top \#2 G. inflata bed is identified during MIS 47 to MIS 41 from the Omma Formation in the Hokuriku District of central Japan.

Based on this revised correlation for the lower part of the succession (below $450 \mathrm{~m}$ CCSF-A), occurrence peaks of subtropical radiolarians could be assigned to MIS 35, 39, 41, 45, 47, and 49 based on the LR04 curve (Lisiecki and Raymo, 2005), as shown in Figure F2. Although the subtropical peak corresponding to MIS 37 was not recognized, Datum B of the N. pachyderma coiling ratio (right coiling dominant), which indicates a warmer climate, could be correlated to this stage. MIS 43 might be missing due to sampling frequency.

\section{Acknowledgments}

We would like to thank IODP Expedition 346 Science party members, IODP, and IODP Core Curators at Kochi Core Center for providing samples and data for this report. We also thank Chris Hollis for reviewing this report. This work was financially supported by the Japan Society for the Promotion of Science (JSPS), Grant numbers 25400504 and 23221022, and the IODP Expedition 346 After Cruise Research Program, JAMSTEC.

\section{References}

Chang, F., Zhuang, L., Li, T., Yan, J., Cao, Q., and Cang, S., 2003. Radiolarian fauna in surface sediments of the northeastern East China Sea. Marine Micropaleontology, 48(3-4):169-204.

https://doi.org/10.1016/S0377-8398(03)00016-1

Gradstein, F.M., Ogg, J.G., Schmitz, M.D., and Ogg, G.M. (Eds.), 2012. The Geological Time Scale 2012: Oxford, United Kingdom (Elsevier).

Ikenoue, T., Okazaki, Y., Takahashi, K., and Sakamoto, T., 2016. Bering Sea radiolarian biostratigraphy and pale- 
oceanography at IODP Site U1341 during the last four million years. Deep Sea Research, Part II: Topical Studies in Oceanography, 125-126:38-55.

https://doi.org/10.1016/j.dsr2.2015.03.004

Itaki, T., 2006. Elutriation technique for extracting radiolarian skeletons from sandy sediments and its usefulness for faunal analysis. Radiolaria, 24:14-18.

Itaki, T., 2007. Historical changes of deep-sea radiolarians in the Japan Sea during the last 640 kyrs. Fossils, 82:4351. (in Japanese with English abstract)

Itaki, T., Komatsu, N., and Motoyama, I., 2007. Orbitaland millennial-scale changes of radiolarian assemblages during the last 220 kyrs in the Japan Sea. Palaeogeography, Palaeoclimatology, Palaeoecology, 247(1-2):115-130. https://doi.org/10.1016/j.palaeo.2006.11.025

Itaki, T., Uchida, M., Kim, S., Shin, H.-S., Tada, R., and Khim, B.-K., 2009. Late Pleistocene stratigraphy and paleoceanographic implications in northern Bering Sea slope sediments: evidence from the radiolarian species Cycladophora davisiana. Journal of Quaternary Science, 24(8):856-865. https://doi.org/10.1002/jqs.1356

Kheradyar, T., 1992. Pleistocene planktonic foraminiferal assemblages and paleotemperature fluctuations in Japan Sea, Site 798. In Pisciotto, K.A., Ingle, J.C., Jr., von Breymann, M.T., Barron, J., et al., Proceedings of the Ocean Drilling Program, Scientific Results, 127/128 (Part 1): College Station, TX (Ocean Drilling Program), 457-470. https://doi.org/10.2973/odp.proc.sr.1271281.149.1992

Kido, Y., Minami, I., Tada, R., Fujine, K., Irino, T., Ikehara, K., and Chun, J.-H., 2007. Orbital-scale stratigraphy and high-resolution analysis of biogenic components and deep-water oxygenation conditions in the Japan Sea during the last 640 kyr. Palaeogeography, Palaeoclimatology, Palaeoecology, 247(1-2):32-49. https://doi.org/10.1016/j.palaeo.2006.11.020

Kitamura, A., and Kimoto, K., 2004. Reconstruction of the southern channel of the Japan Sea at 3.9-1.0 Ma. The Quaternary Research, 43:417-434. (in Japanese with English abstract) https://doi.org/10.4116/jaqua.43.417

Kruglikova, S.B., 1976. Radiolarians in the upper Pleistocene sediments of the boreal and northern subtropical zones of the Pacific Ocean. Oceanology, 16:113-117.

Ling, H.Y., 1973. Radiolaria: Leg 19 of the Deep Sea Drilling Project. In Creager, J.S., Scholl, D.W., et al., Initial Reports of the Deep Sea Drilling Project, 19: Washington (U.S. Government Printing Office), 777-797. https://doi.org/10.2973/dsdp.proc.19.128.1973

Ling, H.Y., 1975. Radiolaria: Leg 31 of the Deep Sea Drilling Project. In Karig, D.E., Ingle, J.C., Jr., et al., Initial Reports of the Deep Sea Drilling Project, 31: Washington (U.S. Government Printing Office), 703-761. https://doi.org/10.2973/dsdp.proc.31.137.1975

Lisiecki, L.E., and Raymo, M.E., 2005. A Pliocene-Pleistocene stack of 57 globally distributed benthic $\delta^{18} \mathrm{O}$ records. Paleoceanography, 20(1):PA1003. https://doi.org/10.1029/2004PA001071
Lombari, G., and Boden, G., 1985. Modern radiolarian global distributions. Special Publication-Cushman Foundation for Foraminiferal Research, 16A.

Maiya, S., Saito, T., and Sato, T., 1976. Late Cenozoic planktonic foraminiferal biostratigraphy of northwest Pacific sedimentary sequences. In Takayanagi, Y., and Saito, T. (Eds.), Progress in Micropaleontology: New York (Micropaleontology Press), 395-422.

Matsuzaki, K.M., and Suzuki, N., 2018. Quaternary radiolarian biostratigraphy in the subarctic northeastern Pacific (IODP Expedition 341 Site U1417) and synchroneity of bioevents across the North Pacific. Journal of Micropaleontology, 37:1-10.

https://doi.org/10.5194/jm-37-1-2018

Matsuzaki, K.M., Suzuki, N., Nishi, H., Takashima, R., Kawate, Y., and Sakai, T., 2014. Middle to late Pleistocene radiolarian biostratigraphy in the water-mixed region of the Kuroshio and Oyashio currents, northeastern margin of Japan (JAMSTEC Hole 902-C9001C). Journal of Micropaleontology, 33(2):205-222.

https://doi.org/10.1144/jmpaleo2013-012

Matul, A., Abelmann, A., Tiedemann, R., Kaiser, A., and Nürnberg, D., 2002. Late Quaternary polycystine radiolarian datum events in the Sea of Okhotsk. Geo-Marine Letters, 22(1):25-32. https://doi.org/10.1007/s00367-002-0093-y

Matul, A., Abelmann, A., Nürnberg, D., and Tiedemann, R., 2009. Stratigraphy and major paleoenvironmental changes in the Sea of Okhotsk during the last million years inferred from radiolarian data. Oceanology, 49(1):101-109. https://doi.org/10.1134/S0001437009010111

Motoyama, I., Yamada, Y., Hoshiba, M., and Itaki, T., 2016. Radiolarian assemblages in surface sediments of the Japan Sea. Paleontological Research, 20(3):176-206. https://doi.org/10.2517/2015PR030

Oba, T., Kato, M., Kitazato, H., Koizumi, I., Omura, A., Sakai, T., and Takayama, T., 1991. Paleoenvironmental changes in the Japan Sea during the last 85,000 years. Paleoceanography, 6(4):499-518. https://doi.org/10.1029/91PA00560

Okazaki, Y., Takahashi, K., Katsuki, K., Ono, A., Hori, J., Sakamoto, T., Uchida, M., Shibata, Y., Ikehara, M., and Aoki, K., 2005. Late Quaternary paleoceanographic changes in the southwestern Okhotsk Sea: evidence from geochemical, radiolarian, and diatom records. Deep-Sea Research, Part II: Topical Studies in Oceanography, 52(16-18): 2332-2350.

https://doi.org/10.1016/j.dsr2.2005.07.007

Sakai, T., 1980. Radiolarians from Sites 434, 435, and 436, northwest Pacific, Leg 56, Deep Sea Drilling Project. In von Huene, R., Nasu, N., et al., Initial Reports of the Deep Sea Drilling Project, 56, 57: Washington, DC (U.S. Government Printing Office), 695-733. https://doi.org/10.2973/dsdp.proc.5657.119.1980

Tada, R., Murray, R.W., Alvarez Zarikian, C.A., Anderson, W.T., Jr., Bassetti, M.-A., Brace, B.J., Clemens, S.C., da Costa Gurgel, M.H., Dickens, G.R., Dunlea, A.G., Galla- 
gher, S.J., Giosan, L., Henderson, A.C.G., Holbourn, A.E., Ikehara, K., Irino, T., Itaki, T., Karasuda, A., Kinsley, C.W., Kubota, Y., Lee, G.S., Lee, K.E., Lofi, J., Lopes, C.I.C.D., Peterson, L.C., Saavedra-Pellitero, M., Sagawa, T., Singh, R.K., Sugisaki, S., Toucanne, S., Wan, S., Xuan, C., Zheng, H., and Ziegler, M., 2015a. Expedition 346 summary. In Tada, R., Murray, R.W., Alvarez Zarikian, C.A., and the Expedition 346 Scientists, Proceedings of the Integrated Ocean Drilling Program, 346: College Station, TX (Integrated Ocean Drilling Program). https://doi.org/10.2204/iodp.proc.346.101.2015

Tada, R., Murray, R.W., Alvarez Zarikian, C.A., Anderson, W.T., Jr., Bassetti, M.-A., Brace, B.J., Clemens, S.C., da Costa Gurgel, M.H., Dickens, G.R., Dunlea, A.G., Gallagher, S.J., Giosan, L., Henderson, A.C.G., Holbourn, A.E., Ikehara, K., Irino, T., Itaki, T., Karasuda, A., Kinsley, C.W., Kubota, Y., Lee, G.S., Lee, K.E., Lofi, J., Lopes, C.I.C.D., Peterson, L.C., Saavedra-Pellitero, M., Sagawa,
T., Singh, R.K., Sugisaki, S., Toucanne, S., Wan, S., Xuan, C., Zheng, H., and Ziegler, M., 2015b. Site U1427. In Tada, R., Murray, R.W., Alvarez Zarikian, C.A., and the Expedition 346 Scientists, Proceedings of the Integrated Ocean Drilling Program, 346: College Station, TX (Integrated Ocean Drilling Program).

https://doi.org/10.2204/iodp.proc.346.108.2015

Tanaka, S., and Takahashi, K., 2005. Late Quaternary paleoceanographic changes in the Bering Sea and the western subarctic Pacific based on radiolarian assemblages. Deep-Sea Research, Part II: Topical Studies in Oceanography, 52(16-18):2131-2149.

https://doi.org/10.1016/j.dsr2.2005.07.002

Initial receipt: 7 February 2017

Acceptance: 15 February 2018

Publication: 2 May 2018

MS 346-202 
Figure F1. Map showing topography of the Japan Sea with warm current flows and paths and location of Site U1427.

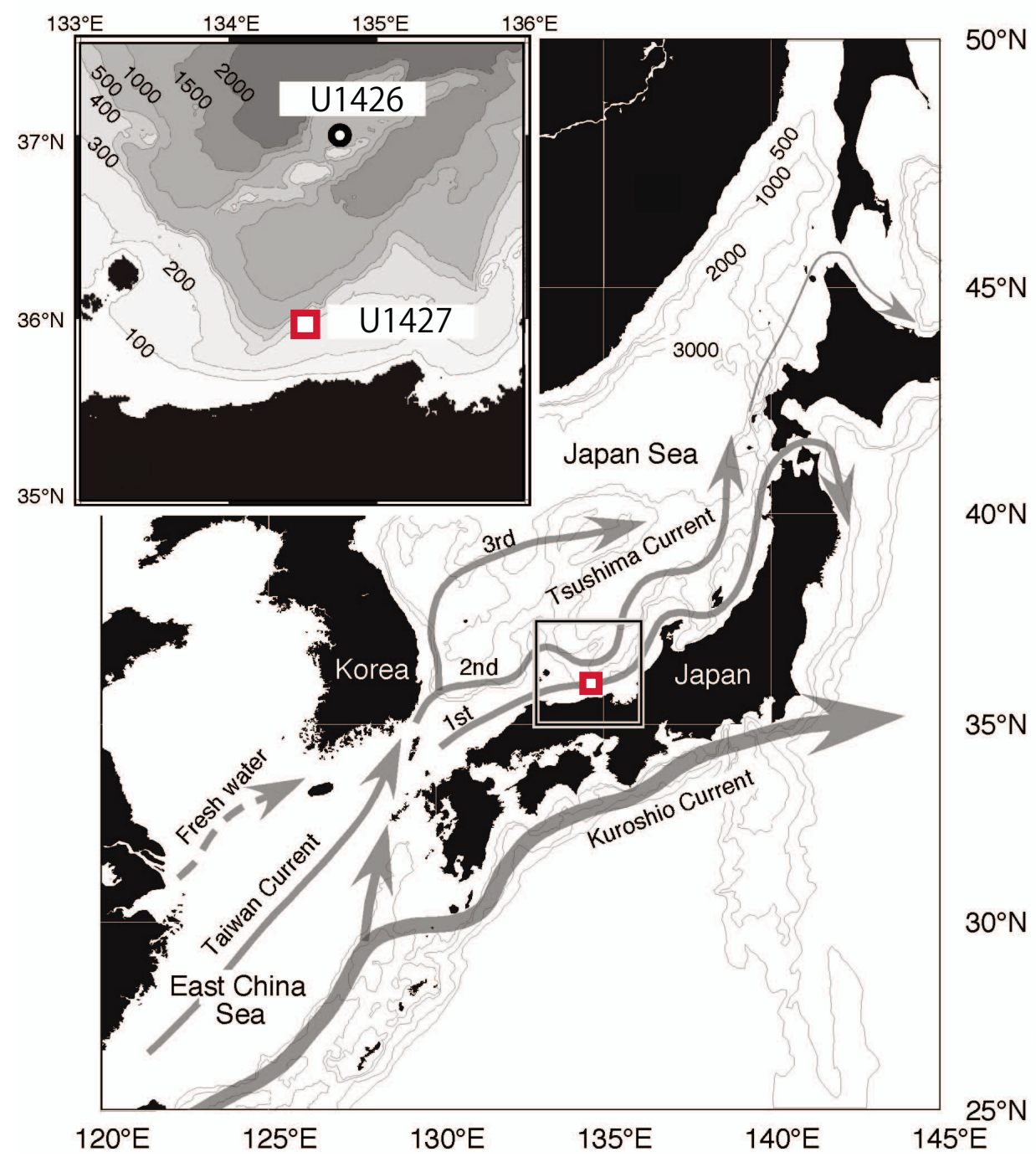


Figure F2. Stratigraphic changes in the absolute abundance of radiolarian subtropical species with the LR04 curve (Lisiecki and Raymo, 2005) and correlations of radiolarian biohorizons. Biostratigraphic datums of planktonic foraminifers and calcareous nannofossils from Hole U1427A reported by Tada et al. (2015b) are also illustrated. $\mathrm{FO}=$ first occurrence, $\mathrm{FCO}=$ first common occurrence, $\mathrm{LO}=$ last occurrence. $\mathrm{MIS}=$ marine isotope stage. $\mathrm{B} / \mathrm{M}=$ Brunhes/Matuyama.

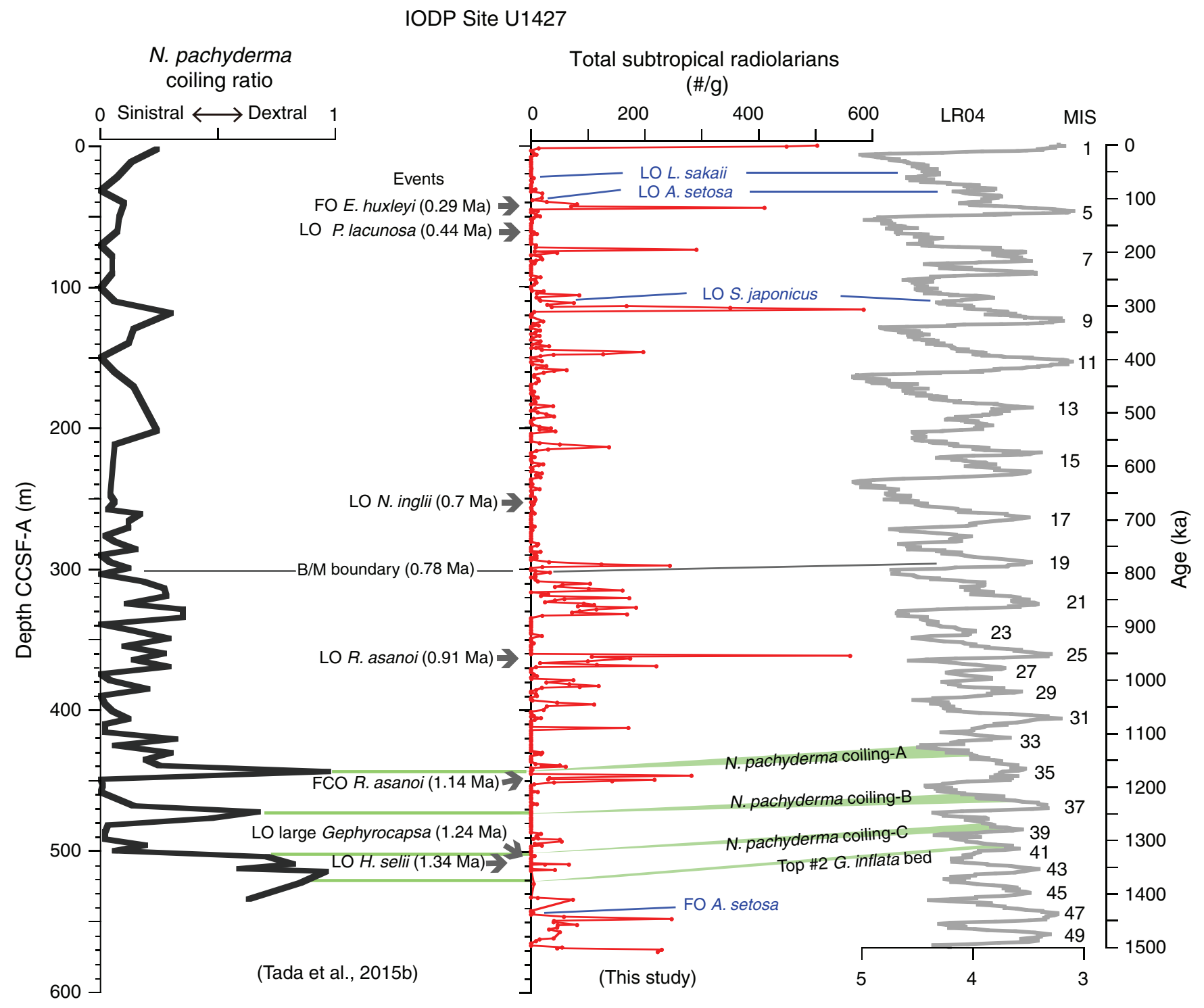


Figure F3. Mapping between the coiling ratio of Neogloboquadrina pachyderma (dextral/sinistral) and the top \#2 Globigerina inflata bed at Site U1427 (this study), ODP Site 798 (Kheradyar, 1992), and Core V20-119 (Maiya et al., 1976). The three datums of the $N$. pachyderma coiling ratio are (A) younger peak, (B) older peak, and (C) significant drop in the ratio. $\mathrm{B} / \mathrm{M}=$ Brunhes/Matuyama.

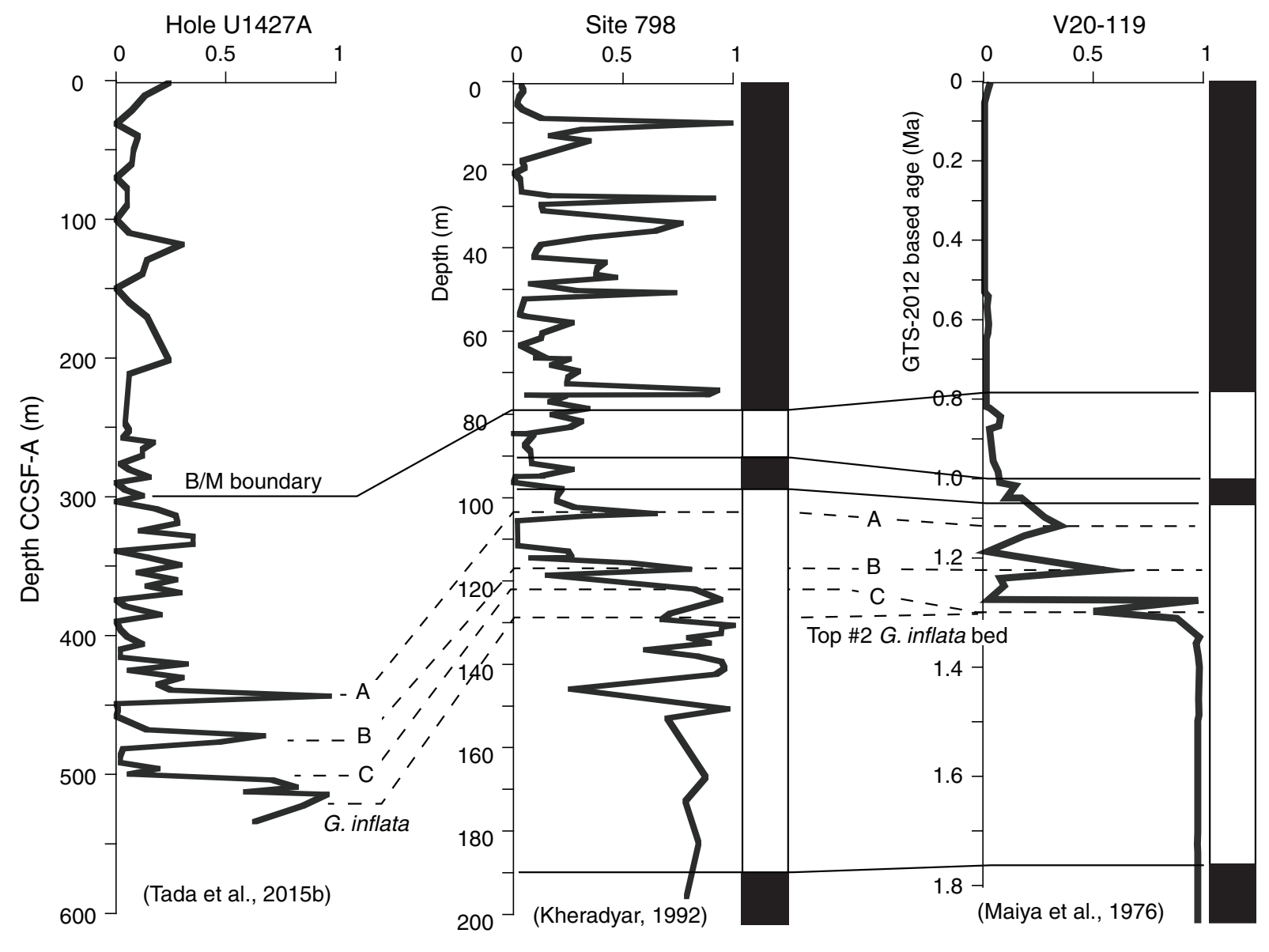


Table T1. Occurrence list of biostratigraphic key species $(+=$ present) and subtropical water species (absolute abundance \#/g). Because the aim of this report is to correlate with the TWC inflow related to eustatic sea level changes, only counts of subtropical taxa are focused. This table is available in CSV format.

Table T2. Radiolarian datum occurrences.

\begin{tabular}{|c|c|c|c|c|c|c|c|}
\hline \multirow[b]{2}{*}{ Datum } & \multirow[b]{2}{*}{$\begin{array}{l}\text { Age } \\
(\mathrm{Ma})\end{array}$} & \multicolumn{2}{|c|}{ U1427A } & \multicolumn{2}{|c|}{ U1427B } & \multicolumn{2}{|c|}{ U1427C } \\
\hline & & $\begin{array}{l}\text { Core, section, } \\
\text { interval }(\mathrm{cm})\end{array}$ & $\begin{array}{c}\text { Depth } \\
\text { CCSF-A (m) }\end{array}$ & $\begin{array}{l}\text { Core, section, } \\
\text { interval }(\mathrm{cm})\end{array}$ & $\begin{array}{c}\text { Depth } \\
\text { CCSF-A (m) }\end{array}$ & $\begin{array}{l}\text { Core, section, } \\
\text { interval }(\mathrm{cm})\end{array}$ & $\begin{array}{c}\text { Depth } \\
\text { CCSF-A (m) }\end{array}$ \\
\hline \multirow{2}{*}{ LO Lychnocanoma sakaii } & 0.054 & $2 \mathrm{H}-\mathrm{CC}$ & 10.92 & $3 \mathrm{H}-4,45-47$ & 20.06 & $2 \mathrm{H}-6,15-17$ & 16.30 \\
\hline & & $3 \mathrm{H}-\mathrm{CC}$ & 21.64 & $3 \mathrm{H}-5,32-34$ & 21.43 & $3 \mathrm{H}-4,45-47$ & 23.06 \\
\hline \multirow{2}{*}{ LO Amphimelissa setosa } & 0.085 & $5 \mathrm{H}-\mathrm{CC}$ & 39.32 & $4 \mathrm{H}-5,48-50$ & 30.63 & $4 \mathrm{H}-5,45-47$ & 33.79 \\
\hline & & $6 \mathrm{H}-\mathrm{CC}$ & 49.94 & $5 \mathrm{H}-3,48-50$ & 37.16 & $5 \mathrm{H}-4,45-47$ & 42.90 \\
\hline \multirow[t]{2}{*}{ LO Schizodiscus japonicus } & 0.29 & $10 \mathrm{H}-\mathrm{CC}$ & 89.56 & $12 \mathrm{H}-7,46-48$ & 102.72 & $12 \mathrm{H}-5,45-47$ & 109.02 \\
\hline & & $11 \mathrm{H}-\mathrm{CC}$ & 100.18 & $14 \mathrm{H}-3,50-52$ & 109.75 & $14 \mathrm{H}-3,45-47$ & 124.54 \\
\hline \multirow{2}{*}{ FO Amphimelissa setosa } & 1.48 & $81 \mathrm{X}-\mathrm{CC}$ & 512.72 & & & & \\
\hline & & $82 X-1,50-52$ & 513.35 & & & & \\
\hline \multicolumn{8}{|c|}{ Coiling ratio of N. pachyderma } \\
\hline Datum A & $1.12-1.13$ & $66 \mathrm{H}-\mathrm{CC}$ & 443.72 & & & & \\
\hline Datum B & $1.21-1.23$ & $72 \mathrm{H}-\mathrm{CC}$ & 472.30 & & & & \\
\hline Datum C & $1.26-1.29$ & $79 \mathrm{H}-\mathrm{CC}$ & 504.23 & & & & \\
\hline
\end{tabular}

$\mathrm{LO}=$ last occurrence, $\mathrm{FO}=$ first occurrence. 